\title{
Correlation between true seed and tuber dormancy in a solanum tuberosum group phureja $\times$ stenotomum population
}

\author{
Muhammad WASIM HAIDER ${ }^{1 *}$, Kathleen G. HAYNES ${ }^{2}$, Chaudhry MUHAMMAD AYYUB ${ }^{1}$, Habat \\ ULLAH ASAD ${ }^{1}$, Naveed Ur REHMAN ${ }^{1}$, Mahmood UI HASSAN ${ }^{1}$ \\ ${ }^{1}$ Institute of Horticultural Sciences, University of Agriculture, Faisalabad, 38040, Pakistan \\ ${ }^{2}$ USDA-ARS, Genetic improvement of Fruits and Vegetables Laboratory, Beltsville, MD 20705, Pakistan
}

How to cite this paper: HAIDER, M. W., HAYNES, K. G., AYYUB, C. M., ASAD, H. U., REHMAN, N. U., HASSAN, M. U. (2019) Correlation between true seed and tuber dormancy in a solanum tuberosum group phureja $\times$ stenotomum population. International Journal of Food Science and Agriculture, 3(3), 183-191.

DOI: $10.26855 /$ ijfsa.2019.09.006

*Corresponding author: Muhammad WASIM HAIDER, Institute of Horticultural Sciences, University of Agriculture, Faisalabad, 38040, Pakistan.

Email: m.wasim.haider@uaf.edu.pk

\begin{abstract}
Short tuber dormancy is desirable when multiple cropping seasons occur yearly, yet most potato cultivars were developed for regions with one growing season per year and have long dormancy. Although several methods exist for breaking tuber dormancy, they can lead to uneven emergence and poor stand counts. Breeding short dormancy cultivars could alleviate this problem. A long-day adapted diploid hybrid population of $S$. tuberosum Group phurejaS. stenotomum ( $p h u-s t n$ ) has been developed with short tuber dormancy. The purpose of this study was to determine if there was a correlation between tuber dormancy in these phu-stn parents and true potato seed dormancy in their offspring, which would allow rapid breeding of short-dormancy germplasm. Tuber dormancy was evaluated for 12 diploid phu-stn parents harvested from three different locations: Presque Isle, Maine (ME), Plymouth, North Carolina (NC) and Beltsville, Maryland (MD) and stored at $7{ }^{\circ} \mathrm{C}$ in MD. Twelve crosses were made among these parents. Each parent was represented twice in the offspring. True potato seed (TPS) from these 12 families were disinfected and soaked in water for 24 hours, dried, and sown in tissue culture. TPS germination was recorded daily for 35 days and the germinated proportion was calculated. The experiment was conducted three times. Parental tuber dormancy ranged from 6-10+ weeks and varied significantly among locations. TPS family proportion germination ranged from 9 to $99 \%$. There was no correlation $(\mathrm{r}=0.01)$ between parental tuber dormancy and seedling vigor index. These results show that the relationship between offspring TPS dormancy and their parent's tuber dormancy is unpredictable. Additional research is needed to determine if selection for early sprouting in the offspring in vitro is correlated with short tuber dormancy in subsequent field generations of these offspring.
\end{abstract}

Keywords

Park, Conflict, Food Security, Participation, Nepal

\section{Introduction}

Potato has been propagated asexually by tubers. However, true potato seed i.e. botanical seed has potential in many tropical and subtropical areas as high quality tubers are difficult to produce in warmer regions, because of tuber-borne pathogens especially viruses. Pakistan is blessed with different agro-climatic zones (Malagamba, 1988)[1-4]. Farmers are raising two crops of potato namely autumn and spring while the third is grown in hilly areas during the summer in 
plain areas. As a result of the short time between harvesting and planting of consecutive crops, farmers have adapted autumn-autumn cycle resulting in poor and expensive crop and seed production. Seed potato from summer crop have only been used as seed to the spring crop for seed multiplication and in autumn for further carrying over autumn to autumn cycle. Hence, short time gap between planting and harvesting of consecutive crops instigate farmers adapt autumn to autumn cycle being the only national potato seed strategy for Pakistan. It would be of great value for potato growers to develop early maturing and short-dormant varieties so the seed could be rotated around from between the crops[5-7].

Currently, in Pakistan a few Dutch-origin potato varieties are grown, have moderate to deep dormancy (Ahmed and Bhutta, 1995); and need to be stored at cold temperatures to enable next planting. But the country does not have enough cold storage facilities. Actually, these cultivars have been developed according to their regional conditions with one growing season per year. Development of early maturing varieties with short dormancy would be beneficial for growers as due to lack of appropriate material, the dormancy breaking methods give uneven emergence and poor stand counts. Unfortunately, issues related to tuber dormancy are rarely investigated in breeding programs[8-10].

Dormancy in potato is an inherent character and characterized as "the incapability of a seed/ tuber to germinate/ sprout in a specific period of time even under favorable environmental factors i.e. temperature, light/ darkness etc. (Baskin and Baskin, 2004; Claassens et al., 2005). Reust and coworkers (2001) studied some attributes while selecting shortgeneration seedlings comprising days to germination, physiological vigor/ rusticity and incubation period. These attributes may possibly be helpful for making selections for short-growing season potato crop. Seed vigor is a principal indicator of seed quality and involves rapid and uniform emergence of normal seedlings within a particular period (Zhu and Hong, 2008). "Physiological vigor/ rusticity" of a seed tuber is measured as the capacity of a clone having its $80 \%$ of tubers sprouted at least $2 \mathrm{~mm}$ long (Pande et al., 2007). The "incubation phase" is the period between the onset of sprouting and tuber initiation on the developing sprouts (Madec and Perennec, 1962). Seed dormancy in potatoes, has been positively correlated with tuber dormancy (Simmonds, 1964). So, the quality seed (TPS) can not only be related to final yields, but might also affect seed tuber quality (Barrington, 1971)[11-15].

Potato breeding program have a first generation of tuber production from botanic seeds, followed by generations of clone selection in the field (Bisognin, 2003). A large number of clones might need to be discarded, since the first generation because of limited number of tubers production having deep dormancy (Bisognin et al., 1998). Since, the dormancy is a character expressed very late. If this character can be correlated with some early expressive characters, much time can be saved by accurate measuring those indirect characters. The seedling emergence in tissue culture and dry matter contents are positively correlated with tuber dormancy and predominately additive in nature (Rashid and Carpena, 1997)[15-17].

The cultivated tetraploids can probably be promising for the highest yield but the diploids in comparison are gaining popularity, having more potential than is yet appreciated (De Maine, 1996). The tetrasomic inheritance of tetraploids also makes potato breeding programs complicated (Iwanaga, 1980). On the other hand, selection progress is more rapid with diploids due to simple disomic inheritance as increasing gene frequency at the $4 x$ level is slower than at the $2 x$ level (Iwanaga, 1980; Jansky, 2009). The hybrid population $S$. phureja $\times$ S. stenotomum was developed in the USA for heat tolerance, adaptation to long days, tuber appearance and high dry matter (Gautney and Haynes, 1983; Haynes and Haynes, 1983). They have gained a significance for their colorful flesh containing higher amount of carotenoids (Brown et al., 2006) and resistance to several diseases i.e. early blight (Christ and Haynes, 2001), resistance to soft rot Erwinias (Wolters and Collins, 1995), bacterial wilt and late blight (Costanzo et al., 2005). The genetic variance for tuber dormancy is very high in S. phureja and S. stenotomum populations (Thompson et al., 1980). So measuring seed dormancy and its correlation with tuber dormancy will be expedient for breeders minimize clone discard, due to either no or late plantlet emergence. The diploid potatoes having chosen characteristics are selected afterwards for the production of tetraploid hybrids through bilateral (BSP) and unilateral (USP) sexual polyploidization. BSP encompasses the cross between the female parent (forms $2 n$ eggs) and the male parent (forms $2 n$ pollen). In contrast, USP involves the cross between the parents producing $2 n$ gametes (either $2 n$ pollen or $2 n$ eggs). The manipulation of $2 n$ gametes and the asexual reproduction system of the potato provide the breeders the unique possibility of accumulating non additive genetic effects at the tetraploid level of the offspring. The objective of the current study is to determine tuber dormancy in a random sample of diploids, and determine if tuber dormancy in the parents is correlated with seedling dormancy in their offspring[17-21]. 


\section{Material and methods}

The 12 random crosses were selected for this study and 40 seeds from each cross were sterilized and soaked in double distilled water. After drying them for 24 hours, one seed was put in each tissue culture tube containing media (Table 1) and labelled with family ID. The temperature and humidity were $19{ }^{\circ} \mathrm{C}$ and $51 \%$, respectively, in tissue culture room. All the tubes were arranged in racks and kept in the growth room. At the time of germination, each genotype was assigned a genotype number in order of germination i.e. WHD 1-1, WHD 1-2, etc. Plantlets were transplanted in greenhouse when there were two sets of true leaves. The tubers of parental genotypes were harvested from three different locations Presque Isle, Maine; Plymouth, North Carolina and BARC, Maryland. The tubers were kept in cold store of BARC, Maryland, USA at $7{ }^{\circ} \mathrm{C}$ and analyzed weekly for sprouting data.

Table 1. The composition of medium used for growing seeds

\begin{tabular}{lll}
\hline No. & Ingredients & Concentration \\
\hline 1 & $\mathrm{H}_{2} \mathrm{O}$ (Double distilled) & $1 \mathrm{~L}$ \\
2 & Thiamine- $\mathrm{HCl}\left(0.04 \mathrm{~g} / 100 \mathrm{ml} \mathrm{DD} \mathrm{H} \mathrm{H}_{2} \mathrm{O}\right)$ & $1 \mathrm{~mL}$ \\
3 & MS Basal salts & $4.33 \mathrm{~g}$ \\
4 & Inositol (Myo-Inositol) & $0.10 \mathrm{~g}$ \\
5 & Sucrose & $20 \mathrm{~g}$ \\
6 & $\mathrm{Na} \mathrm{H}_{2} \mathrm{PO}_{4}$ & $0.17 \mathrm{~g}$ \\
7 & $1 \mathrm{~N} \mathrm{NaOH}$ & $1.3 \mathrm{~mL}$ \\
8 & $\mathrm{PPM}$ & $1 \mathrm{~mL}$ \\
9 & Phytagel & $1.57 \mathrm{~g}$ \\
\hline
\end{tabular}

\subsection{Study of true seed dormancy}

\subsubsection{Germination (\%)}

The number of germinated seeds was recorded on a daily basis and their percentage was calculated.

\subsubsection{Average seedling length $(\mathrm{cm})$}

The seedling height was taken at $14^{\text {th }}$ and $21^{\text {st }}$ day from every culture tube and their average was calculated.

\subsubsection{Seedling vigor index}

Vigor index was calculated as VI $=\mathrm{S} \times \Sigma(\mathrm{Gt} / \mathrm{Dt})$ (Zhu and Hong, 2008); where S is seedling height of the $14^{\text {th }}$ day, Gt is number of germinated seeds in the "tth" day, Dt is number of days from the first day to the "tth" day.

\subsection{Study of tuber dormancy}

\subsubsection{Dormancy duration (days)}

Dormancy duration was counted as number of weeks from harvesting to sprouting when $80 \%$ of the tubers (24 tubers for each genotype), with dormancy considered 'broken' when sprouts reached $2 \mathrm{~mm}$ in length (Pande et al., 2007). Tubers were scored daily for dormancy.

\subsubsection{Sprouting (\%)}

Sprouting percentage was calculated as percentage of sprouted tubers over total number of tubers. It was determined at the end of experiment when approximately all the tubers had visible sprouts.

\subsection{Statistical analysis}

For the statistical analysis, the experimental data were subjected to analysis of variance (ANOVA) using Statistix $9^{\circledR}$ for Windows (Analytical Software, Tallahassee, USA). Fisher's least significant difference (LSD) was used following a 
significant $(P<0.05)$ F-test. Correlation was analyzed by the general linear models procedure in SAS, version 9.2 (Cary, NC) as described (Anjum et al., 2018).

\section{Results}

\subsection{Study of true seed dormancy}

\subsubsection{Germination (\%)}

The genotypes differed significantly for germination percentage. The seeds of genotype WHD-7 had maximum germination percentage, statistically similar to that of WHD-4 seeds. In contrast, seeds of genotype WHD-6 did not germinate at all (Table 2).

\subsubsection{Average seedling length $(\mathrm{cm})$}

Significant variations in seedling length were observed among genotypes. The genotypes WHD-4, WHD-7, WHD-8 and WHD-9 were found to have the longest seedlings which were statistically comparable with each other (Table 2). The smallest seedling was observed in WHD-6.

\subsubsection{Seedling vigor index}

The genotypes had significant differences for SVI. The highest SVI was noted in genotypes WHD-4 and WHD-7 and lowest in WHD-6 following WHD-1, WHD-12, WHD-3 and WHD-2 (Table 2).

Table 2. Mean comparison of true seed germination percentage, seedling length and seedling vigor index in 12 potato genotypes.

\begin{tabular}{llccc}
\hline Genotypes & Parents $($ Female $\times$ male) & $\begin{array}{c}\text { Germination } \\
\text { \%age }\end{array}$ & $\begin{array}{c}\text { Average seedling } \\
\text { length }(\mathbf{c m})\end{array}$ & Seedling vigor index \\
\hline WHD-1 & BD1301-3 $\times$ BD1315-3 & $5.83 \mathrm{fg}$ & $14.11 \mathrm{~b}$ & $3.10 \mathrm{f}$ \\
WHD-2 & BD1306-4 $\times$ BD1335-4 & $15.83 \mathrm{ef}$ & $12.32 \mathrm{~b}$ & $6.89 \mathrm{ef}$ \\
WHD-3 & BD1306-4 $\times$ BD1341-5 & $13.33 \mathrm{f}$ & $14.14 \mathrm{~b}$ & $6.76 \mathrm{ef}$ \\
WHD-4 & BD1308-3 $\times$ BD1330-3 & $90.83 \mathrm{ab}$ & $17.68 \mathrm{ab}$ & $53.56 \mathrm{a}$ \\
WHD-5 & BD1311-4 $\times$ BD1310-1 & $30.83 \mathrm{~d}$ & $13.94 \mathrm{~b}$ & $11.94 \mathrm{de}$ \\
WHD-6 & BD1311-4 $\times$ BD1334-2 & $0.00 \mathrm{~g}$ & $0.00 \mathrm{c}$ & $0.00 \mathrm{f}$ \\
WHD-7 & BD1312-5 $\times$ BD1334-2 & $94.17 \mathrm{a}$ & $17.88 \mathrm{ab}$ & $49.05 \mathrm{a}$ \\
WHD-8 & BD1315-3 $\times$ BD1310-1 & $50.83 \mathrm{c}$ & $21.01 \mathrm{a}$ & $31.50 \mathrm{c}$ \\
WHD-9 & BD1330-3 $\times$ BD1308-3 & $82.50 \mathrm{~b}$ & $17.77 \mathrm{ab}$ & $40.97 \mathrm{~b}$ \\
WHD-10 & BD1341-5 $\times$ BD1301-3 & $25 \mathrm{de}$ & $14.68 \mathrm{~b}$ & $11.62 \mathrm{de}$ \\
WHD-11 & BD1421-5 $\times$ BD1312-5 & $32.5 \mathrm{~d}$ & $14.59 \mathrm{~b}$ & $16.11 \mathrm{~d}$ \\
WHD-12 & BD1421-5 $\times$ BD1335-4 & $9.16 \mathrm{fg}$ & $13.48 \mathrm{~b}$ & $3.85 \mathrm{f}$ \\
LSD G $(P \leq 0.05)$ & 10.367 & 6.050 & 7.564 & \\
\hline
\end{tabular}

Treatment means followed by the same letter are not significantly different. LSD = Least significant difference.

\subsection{Study of tuber dormancy}

The dormancy period and sprouting percentage of tubers from 13 Solanum phureja $\times$ S. stenotomum hybrids grown at three different sites in USA was determined immediately after harvest.

\subsubsection{Dormancy duration}

Statistically significant differences in dormancy duration were observed under main effects of location and genotype and their interaction (Table 3). The tubers harvested from Maine and Beltsville had shorter tuber dormancy than had the North Carolina tubers. The longest dormancy duration was observed in tubers of genotypes BD1310-1, BD13354, BD1315-3 and BD1326-1 whereas the genotypes BD1308-3 and BD1301-3 had the shortest tuber dormancy. The genotypes BD1312-5, BD1334-2 and BD1306-4 did not have their tuber dormancy break at all. 
Table 3. Tuber dormancy duration and sprouting percentage of 13 parental genotypes from three different locations.

\begin{tabular}{|c|c|c|c|}
\hline Factors & & Dormancy duration (Weeks) & Sprouting \%age \\
\hline \multirow[t]{3}{*}{ Location (L) } & Maine & $8.15 b$ & $81.43 a$ \\
\hline & Beltsville & $8.38 \mathrm{~b}$ & $81.30 \mathrm{a}$ \\
\hline & North Carolina & $8.76 \mathrm{a}$ & $70.46 b$ \\
\hline LSD L $(P \leq 0.05)$ & & 0.231 & 1.227 \\
\hline \multirow{13}{*}{ Genotype (G) } & BD1310-1 & $9.00 \mathrm{a}$ & $88.35 \mathrm{c}$ \\
\hline & BD1334-2 & NDB & $43.11 \mathrm{~g}$ \\
\hline & BD1306-4 & NDB & $32.28 \mathrm{~h}$ \\
\hline & BD1326-1 & $9.00 \mathrm{a}$ & $79.24 d$ \\
\hline & BD1308-3 & $6.33 d$ & $93.58 b$ \\
\hline & BD1335-4 & $9.00 \mathrm{a}$ & $76.64 \mathrm{e}$ \\
\hline & BD1301-3 & $6.67 \mathrm{~cd}$ & $100 \mathrm{a}$ \\
\hline & BD1330-3 & $7.00 \mathrm{c}$ & $90.58 \mathrm{c}$ \\
\hline & BD1311-4 & $7.00 \mathrm{c}$ & $89.05 \mathrm{c}$ \\
\hline & BD1315-3 & $9.00 \mathrm{a}$ & $66.31 \mathrm{f}$ \\
\hline & BD1341-5 & $7.00 \mathrm{c}$ & $95.08 \mathrm{~b}$ \\
\hline & BD1421-5 & $7.67 \mathrm{~b}$ & $89.15 \mathrm{c}$ \\
\hline & BD1312-5 & NDB & $67.17 \mathrm{f}$ \\
\hline LSD G $(P \leq 0.05)$ & & 0.481 & 2.553 \\
\hline $\mathrm{LSD} \mathrm{L} \times \mathrm{G}(P \leq 0.05)$ & & 1.353 & 4.423 \\
\hline
\end{tabular}

Treatment means followed by the same letter are not significantly different. LSD = Least significant difference. NDB = No dormancy break.

The maximum tuber dormancy was recorded in genotypes BD1310-1 and BD1330-3 harvested from any experimental location and BD1326-1, BD1315-3, BD1335-4 and BD1421-5 harvested from the Maine and Beltsville. The shortest tuber dormancy was observed in BD1308-3 and BD1341-5 from any experimental location, BD1301-3 from the Maine and Beltsville and BD1311-4 from the Maine and North Carolina (Table 4).

Table 4. Mean comparison of tuber dormancy duration of under the interactive effect of location $\times$ genotype.

\begin{tabular}{lccc}
\hline & & Location & North Carolina \\
\cline { 2 - 4 } Genotype & Maine & Beltsville & $9.00 \mathrm{a}$ \\
BD1310-1 & $9.00 \mathrm{a}$ & $9.00 \mathrm{a}$ & NDB \\
BD1334-2 & NDB & NDB & NDB \\
BD1306-4 & NDB & NDB & NDB \\
BD1326-1 & $9.00 \mathrm{a}$ & $9.00 \mathrm{a}$ & $7.00 \mathrm{bc}$ \\
BD1308-3 & $6.00 \mathrm{c}$ & $6.00 \mathrm{c}$ & NDB \\
BD1335-4 & $8.00 \mathrm{ab}$ & $9.00 \mathrm{a}$ & $8.00 \mathrm{ab}$ \\
BD1301-3 & $6.00 \mathrm{c}$ & $6.00 \mathrm{c}$ & $9.00 \mathrm{a}$ \\
BD1330-3 & $8.00 \mathrm{ab}$ & $9.00 \mathrm{a}$ & $7.00 \mathrm{bc}$ \\
BD1311-4 & $6.00 \mathrm{c}$ & $8.00 \mathrm{ab}$ & NDB \\
BD1315-3 & $9.00 \mathrm{a}$ & $8.00 \mathrm{ab}$ & $7.00 \mathrm{bc}$ \\
BD1341-5 & $7.00 \mathrm{bc}$ & $7.00 \mathrm{bc}$ & $7.00 \mathrm{bc}$ \\
BD1421-5 & $8.00 \mathrm{ab}$ & $8.00 \mathrm{ab}$ & NDB \\
BD1312-5 & NDB & NDB &
\end{tabular}

Treatment means followed by the same letter are not significantly different. NDB = No dormancy break. 


\subsubsection{Sprouting (\%)}

The main effects of locations and genotypes had significant effect on sprouting percentage of potato tubers and also had their interaction. Sprouting percentage (\%) for genotypes and locations is presented in Table 3. The tubers harvested from Maine and Beltsville had highest sprouting percentage compared to the North Carolina harvested tubers.

The lowest sprouting percentage was noted in genotype BD1306-4 harvested from the Beltsville, while the highest percentage was noted in BD1308-3, BD1301-3 and BD1330-3 harvested from the Maine, and BD1308-3 and BD1341-5 harvested from the Beltsville (Table 5).

Table 5. Mean comparison of sprouting \%age of tubers under the interactive effect of location $\times$ genotype.

\begin{tabular}{llcc}
\hline \multirow{2}{*}{ Genotype } & \multicolumn{3}{c}{ Location } \\
\cline { 2 - 4 } & Maine & Beltsville & North Carolina \\
\hline BD1310-1 & $88.40 \mathrm{fghi}$ & $93.81 \mathrm{cde}$ & $82.83 \mathrm{jkl}$ \\
BD1334-2 & $45.17 \mathrm{p}$ & $40.81 \mathrm{p}$ & $43.35 \mathrm{p}$ \\
BD1306-4 & $34.76 \mathrm{q}$ & $40.81 \mathrm{r}$ & $33.77 \mathrm{q}$ \\
BD1326-1 & $82.74 \mathrm{jkl}$ & 81.441 & $73.55 \mathrm{~m}$ \\
BD1308-3 & $100.00 \mathrm{a}$ & $96.96 \mathrm{abc}$ & $83.79 \mathrm{jkl}$ \\
BD1335-4 & $86.58 \mathrm{ghij}$ & $85.70 \mathrm{ijkl}$ & $57.63 \mathrm{o}$ \\
BD1301-3 & $100.00 \mathrm{a}$ & $100.00 \mathrm{a}$ & $100.00 \mathrm{a}$ \\
BD1330-3 & $100.00 \mathrm{a}$ & $90.29 \mathrm{efgh}$ & 81.441 \\
BD1311-4 & $92.11 \mathrm{def}$ & $92.08 \mathrm{def}$ & $82.96 \mathrm{jkl}$ \\
BD1315-3 & $81.59 \mathrm{kl}$ & $99.35 \mathrm{fghi}$ & $28.98 \mathrm{r}$ \\
BD1341-5 & $90.54 \mathrm{efg}$ & $88.91 \mathrm{fghi}$ & $95.48 \mathrm{bcd}$ \\
BD1421-5 & $92.61 \mathrm{cdef}$ & $71.05 \mathrm{~m}$ & $85.94 \mathrm{hijk}$ \\
BD1312-5 & $64.19 \mathrm{n}$ & $66.26 \mathrm{n}$ \\
\hline
\end{tabular}

Treatment means followed by the same letter are not significantly different.

\section{Discussion}

The variance among progenies for seedling vigor index (SVI) was significant at 5\% level for all individuals. Parental tuber dormancy ranged from 6-10+ weeks and SVI ranged from 0 to 53.6. Correlation matrix is multivariate analysis which is helpful to determine direct and indirect association among different traits (Anjum et al., 2018; Ahmad et al., 2019). However, no correlation $(r=0.01)$ was observed between parental tuber dormancy and SVI. So, the relationship between offspring TPS dormancy and their parent's tuber dormancy is unpredictable[22-24].

The average temperature in Presque Isle, Maine ranges from $14-18^{\circ} \mathrm{C}$, in Plymouth, North Carolina from $12-26^{\circ} \mathrm{C}$ and $18-24^{\circ} \mathrm{C}$ in greenhouse of BARC, Maryland during the potato growth period. So, the uplands experience consistently lower air and soil temperature than the lowlands. As shown in Tables $\mathbf{4}$ and 5, dormancy duration and sprouting percentage varied significantly under the interactive effect of location $\times$ genotype. The results of the current study are contradictory to many previous reports which found the minor impact of seed production site on dormancy duration and sprout growth (Wurr, 1979). The previous reports show a general agreement that temperature is the dominant factor in described effects of site of seed production on regrowth of progeny tubers. But, O'Brien and Allen (1986) rejected this interpretation of consistent relationship between temperature at the sites and dormancy duration. Their study suggested stage of crop growth at the time of defoliation and removal of tubers as determinants for dormancy duration[25-28].

One of the significant advantage of manipulating at the diploid level is that it is possible to breed for and fix traits under recessive genetic control, while it is almost impossible to fix recessive alleles at the tetraploid level. True potato seed of Solanum tuberosum is commonly used for preservation of wild germplasm and cultivated potatoes (Hawkes et al., 2000). TPS can be rapidly increased for agronomic and storage trials when a potential new hybrid cultivar is identified. In addition, while it is difficult to overcome dormancy in tubers. TPS dormancy can be easily overcome using gibberellic acid (Jansky et al., 2012). Simmonds (1963) suggested that selection of genotypes at seed level has 
fundamental importance. The breeder can select for early sprouting by picking the first germinator in a seed lot and for slow sprouting (good keeping quality) could advance his selection by picking the slowest germinator. As potatoes are propagated through tubers, the increase of clonal material proceeds slowly (Haynes et al., 2012). For example, in ARS Potato Breeding Program, a genotype advances from a single hill in the first field generation to 60 hills in the third field generation. Genotypes in third field generation are available to cooperators for multi-location evaluation. By that time, less than $1 \%$ of the genotypes from the original population remain. Most potato breeding programs work in a similar fashion. In this study, the values of seedling vigor index of all the progenies having a long dormant parent, were lower except WHD-7, which had the high value of seedling vigor index with both parents were long-dormant (Table 6). Both parents of WHD-7 did not break their dormancy. WHD-2 and WHD-8 also had long dormant parents but had lower values (6.89 and 31.50) of seedling vigor index. The highest vigor index was observed in seedlings of WHD-4 which had both of its parents short-dorman[29-31]t.

Table 6. Seed and tuber dormancy in edible diploid potatoes.

\begin{tabular}{|c|c|c|c|}
\hline Progenies & Parents (Female $\times$ male) & $\begin{array}{l}\text { Parental tuber dormancy } \\
\text { (weeks) }\end{array}$ & Seedling vigor index \\
\hline WHD-1 & BD1301-3 × BD1315-3 & $6.67,9.00$ & $3.10 \mathrm{f}$ \\
\hline WHD-2 & BD1306-4 × BD1335-4 & NDB, 9.00 & $6.89 \mathrm{ef}$ \\
\hline WHD-3 & BD1306-4 × BD1341-5 & NDB, 7.00 & $6.76 \mathrm{ef}$ \\
\hline WHD-4 & BD1308-3 × BD1330-3 & $6.33,7.00$ & $53.56 \mathrm{a}$ \\
\hline WHD-5 & BD1311-4 × BD1310-1 & $7.00,9.00$ & 11.94de \\
\hline WHD-6 & BD1311-4 × BD1334-2 & 7.00, NDB & $0.00 \mathrm{f}$ \\
\hline WHD-7 & BD1312-5 × BD1334-2 & NDB, NDB & $49.05 \mathrm{a}$ \\
\hline WHD-8 & BD1315-3 × BD1310-1 & $9.00,9.00$ & $31.50 \mathrm{c}$ \\
\hline WHD-9 & BD1330-3 × BD1308-3 & $7.00,6.33$ & $40.97 b$ \\
\hline WHD-10 & BD1341-5 × BD1301-3 & $7.00,9.00$ & $11.62 \mathrm{de}$ \\
\hline WHD-11 & BD1421-5 × BD1312-5 & 7.67, NDB & $16.11 d$ \\
\hline WHD-12 & BD1421-5 × BD1335-4 & $7.67,9.00$ & $3.85 \mathrm{f}$ \\
\hline LSD G $(P \leq 0.05)$ & 10.367 & 7.564 & \\
\hline
\end{tabular}

Treatment means followed by the same letter are not significantly different. LSD = Least significant difference.

\section{Conclusion}

From the results, it is clear that the relationship between offspring TPS dormancy and their parent's tuber dormancy is unpredictable. Additional research is needed to determine if selection for early sprouting in the offspring in vitro is correlated with short tuber dormancy in subsequent field generations of these offspring.

\section{Acknowledgments}

Funds for this research were provided by the Higher Education Commission, Pakistan and seed material by the Beltsville Agricultural Research Center, United States Department of Agriculture, USA.

\section{Literature cited}

[1] Ahmad, R., Malik, W. and Anjum, M.A. (2019). Genetic Diversity and Selection of Suitable Molecular Markers for Characterization of Indigenous Zizyphus Germplasm. Erwerbs-Obstbau, 3: 1-9.

[2] Ahmed, S.I., and Bhutta, A.R. (1995). Production of disease-free seed potato: Present status and future areas of research and development in Pakistan. Research presented at National Seminar on Research and Development of 
Potato Production in Pakistan. Pak-Swiss Potato Development Project. (Pakistan Agricultural Research Council, Islamabad).

[3] Anjum, M.A., Rauf, A., Bashir, M.A. and Ahmad, R. (2018). The evaluation of biodiversity in some indigenous Indian jujube (Zizyphus mauritiana) germplasm through physico-chemical analysis. Acta Sci. Polonor. Hortorum Cultus, 17(4): 39-52.

[4] Barrington, J.F. (1971). The necessity for high-quality vegetable seed. HortSci. 6, 550-551.

[5] Baskin, J.M., and Baskin, C.C. (2004). A classification system for seed dormancy. Seed Sci. Res. 14: 1-16.

[6] Bisognin, D.A. (2003). Melhoramento da batata para resistência a doenças. In cultivo da batata na região sul do Brasil, A.S. Pereira and J.O. Daniels, eds. (Embrapa Informação Tecnológica, Brasília), p. 125-142.

[7] Bisognin, D.A., Centenaro, R., and Missio, E.L. (1998). Uso do ácido giberélico na quebra de dormência e de dominância apical em batata. Ciência Rural 28, 205-213.

[8] Christ, B.J., and Haynes, K.G. (2001). Inheritance of resistance to early blight disease in a diploid potato population. Plant Breed. 120, 169-172.

[9] Claassens, M.M.J., Verhees, J., van der Plas, L.H.W., van der Krol, A.R., and Vreugdenhil, D. (2005). Ethanol breaks dormancy of the potato tuber apical bud. J. Expt. Bot. 56:2515-2525.

[10] Costanzo, S., Simko, I., Christ, B.J., and Haynes, K.G. (2005). QTL analysis of late blight resistance in a diploid potato family of Solanum phureja $\times$ S. stenotomum. Theor. Appl. Genet. 111, 609-617.

[11] De Maine, M.J. (1996). An assessment of true potato seed families of Solanum phureja. Potato Res. 39, $323-332$.

[12] Gautney, T.L., and Haynes F.L. (1983). Recurrent selection for heat tolerance in diploid potatoes (Solanum tuberosum subsp. phureja and stenotomum). Amer. J. Potato Res. 60, 537-542.

[13] Hawkes, J.G., Maxted, N., and Fort-Lloyd, B.V. (2000). The ex-situ conservation of plant genetic resources. Kiuwer academyc publishers. The University of Birmingham, UK.

[14] Haynes, K.G., and Haynes, F.L. (1983). Stability of high specific gravity genotypes of potatoes under high temperatures. Amer. J. Potato Res. 60, 17-26.

[15] Haynes, K.G., Gergela, D.M., Hutchinson, C.M., Yencho, G.C., Clough, M.E., Henninger, M.R., Halseth, D.E., Sandsted, E., Porter, G.A., and Ocaya, P.C. (2012). Early generation selection at multiple locations may identify potato parents that produce more widely adapted progeny. Euphytica 186, 573-583.

[16] Iwanaga, M. (1980). Breeding at the 2x level for combined pest and disease resistance using wild species and extracted haploids from selected tetraploid clones. Paper presented at: International Conference on "Utilization of the genetic resources of the potato III". Centro Internacional de la Papa, Lima, Peru.

[17] Jansky, S. (2009). Breeding, genetics and cultivar development. In Advances in potato chemistry and technology, J. Singh, and L. Kaur, eds. (Academic Press, Burlington, Vermont, USA), p. 27-62.

[18] Jansky, S., Hamernik, A., and Cai, X. (2012). Rapid cycling with true potato seed. Seed Sci. Technol. 40, $43-50$.

[19] Madec, P., and Perennec, P. (1962). Les relations entre l'induction de la tuberisation et la croissance chez la plante de pomme de terre (Solanum tuberosum L.). Ann. Physiol. Veg. 4, 5-84.

[20] Malagamba, P. (1988). Potato production from true seed in tropical climates. HortSci. 23: 495-500.

[21] O'Brien, P.J., and Allen, E.J. (1986). Effects of site of seed production on seed yields and regrowth of progeny tubers in potatoes. J. Agri. Sci. 107, 83-101.

[22] Pande, P.C., Singh, S.V., Pandey, S.K., and Singh, B. (2007). Dormancy, sprouting Behaviour and weight loss in Indian potato (Solanum tuberosum) varieties. Indian J. Agri. Sci. 77, 715-720. 
[23] Rashid, M.H., and Carpena, A.L. (1997). Genetic variability for tuber dormancy and associated traits in potato (Solanum tuberosum L.). Philipp. J. Crop Sci. 22, 125-130.

[24] Reust, W., Winiger, F.A., Hebeisen, T., and Dutoit J.P. (2001). Assessment of the physiological vigor of new potato cultivars in Switzerland. Potato Res. 44, 11-17.

[25] Simmonds, N.W. (1963). Correlated seed and tuber dormancy in potatoes. Nature 197, 720-721.

[26] Simmonds, N.W. (1964). The genetics of seed and tuber dormancy in the cultivated potatoes. Heredity 19, 489-504.

[27] Simmonds, N.W. (1965). Attempted graft transmission of potato tuber dormancy. Eur. J. Potato Res. 8, 197-199.

[28] Thompson, P., Haynes, F., and Moll, R. (1980). Estimation of genetic-variance components and heritability for tuber dormancy in diploid potatoes. Am. J. Potato Res. 57, 39-46.

[29] Wolters, P.J.C.C., and Collins, W.W. (1995). Estimation of genetic parameters for resistance to Erwinia soft rot, specific gravity, and calcium concentration in diploid potatoes. Crop Sci. 35, 1346-1352.

[30] Wurr, D.C.E. (1979). The effect of the site of seed potato production on subsequent sprout growth and tuber yield. J. Agri. Sci. 92, 227-233.

[31] Zhu, S.Y., and Hong, D.L. (2008). Comparison between two hybrid cultivars of indica rice (Oryza sativa L.) in seed vigor and biochemical traits after aging. Chinese J. Eco-Agric. 16: 396-400. 